\title{
CORRESPONDENCE
}

\section{Animal committees}

SIR - Your article "Protection for laboratory animals?"' (Nature 17 September, p.173) presents a rational and realistic appraisal of the present dilemma concerning the ethical use of animals in experimentation being faced by the scientific community, the animal welfare community and the legislator.

It was of significant interest to the Canadian Council on Animal Care (CCAC) that the article concluded with the suggestion of building into a new system of regulation the establishment of "a committee at every important centre at which animals are used that would be empowered to sanction (or not to sanction) proposed uses of laboratory animals". The CCAC, established as a committee of the Association of Universities and Colleges of Canada in 1968 "to work for the improvement in the care and use of animals on a Canada-wide basis", has had, as its cornerstone, the development of local committees on animal care, at every institution in the country using animals in research. It was, and is, the intention that this committee should act as the "conscience" of the institution in ensuring ethical animal use is practised.

We recognize that we are dealing with human beings whose abilities and motivation vary. Therefore, some committees are more effective than others. However, it is our objective to continue to monitor the activities of these committees, in order to ensure that the weaker ones are made strrong, and the stronger ones continue to be strengthened.

It is our opinion, and one based on experience, that a local committee comprising conscientious and strongly-motivated members can do more than legislation to ensure the ethical treatment of animals in research.

H.C. ROWSEL

Canadian Council on Animal Care,

Ottawa, Ontario, Canada

\section{On chemical war}

SIR - As noted by David Dickson (Nature 1 October, p.327) and Philip Campbell (Nature 22 October, p.598) the last few months have seen a potentially dangerous escalation in chemical warfare. This escalation was symbolized by the Reagan

Administration's decision in February to build a new nerve gas munitions plant in Arkansas, approved by the Senate at the end of May. US stockpiles of nerve gas already stand at well over 10,000 tons and while Warsaw Pact stockpiles certainly exist, their quantity is not known. France also has the weapons. The United States is known to have been pressing for a British contribution to its build-up, whether by stock-piling US weapons or other means, even though our government continues to endorse the policy which led to the disposal of the British stockpile in 1957 and the decision not to develop a replacement. Chemical warfare is prohibited by the Geneva protocol and customary international law.

A new chemical arms race in Europe would be an additional hazard over and above that already presented by nuclear weapons. Furthermore, it would impose new military direction and priorities on research and development in the life sciences and biotechnology. Currently, the Ministry of Defence is in contract with British universities to the tune of $£ 5$ million per annum. With bleak prospects in front of them, and the reduced level of funding by the research councils, university departments may be tempted to seek defence contracts and acquiesce to all that these entail.

We therefore call on scientific and technological colleagues not to participate in research associated with the development and production of chemical weapons; to urge the British government to forgo the production and stockpiling of chemical weapons in the United Kingdom; and to press the government to:

(1) Withdraw its reservation of the right to retaliate in kind made by Britain when ratifying the 1925 Geneva Protocol.

(2) Resubmit the draft Chemical Weapons Convention tabled by Britain in 1976, revised to incorporate new proposals on verification, consultation, scope and confidence-building measures.

(3) Promote specific negotiations on the withdrawal of chemical weapons from both sides of Europe.

A significant start in this direction has already been made, namely the support of 2,000 colleagues, including five Nobel laureates, in science, technology and medical faculties throughout Britain. Further support would be welcome.

SEAN MURPhy
Alastair Hay
Julian PERry Robinson
Open University, University of
Leeds and University of Sussex, UK

\section{Cancer monoclonals}

$\mathrm{S}_{\mathrm{R}}$ - The use of monoclonal antibodies in the treatment of cancer is at present being assessed and there is a section of the biomedical community, both scientific and administrative, that believes empirical clinical trials of monoclonal antibodies and toxin-antibody conjugates should be conducted immediately I wish to present the arguments for a more orderly, scientific and cautious approach.

Three major points can be made in support of the latter case. The first is scientific: it is important to gather as much information as possible before clinical trials with monoclonal antibodies about the tissue distribution of the target antigen, chemical structure and so on. This is for two reasons. (1) The factors involved in either the success or failure of serotherapy cannot be assessed without this basic information. (2) The potential risks or benefits to the patient cannot be accurately measured - this is illustrated by two recent publications. The first reported the (unsuccessful) use of a monoclonal antibody against CALLA antigen in the serotherapy of acute lymphoblastic leukaemia'; the second that the CALLA antigen was not confined to lymphoid cells but was present on several other tissues, particularly in the kidney. 2 .

The second argument is ethical. The minimum right of a terminally ill cancer patient subjected to experimental therapy is that every effort has been made to assess the potential deleterious effects of the proposed therapy. Moreover, it can be argued that the patient should also expect the potential benefits of the treatment to outweigh the potential risks.

The final argument against empirical therapeutic trials of monoclonal antibodies before extensive preclinical testing is that of the relationship between the biomedical community and the general public. In the past, cancer patients and their families have had their expectations of more effective treatments for cancer raised unrealistically by the early optimistic reports of clinical trials with transfer factor, BCG and, more recently, interferon. The biomedical community would be well-advised to avoid a similar situation with monoclonal antibodies.

IAN S. Trowbridge

Department of Cancer Biology,

The Salk Institute, California, USA

Ritz, J. et al. Blood 58, 14]-152 (1981)

2. Metzgar, R.S., Borowitz, M.J., Jones, N.H. \& Dowell, B.L. J. exp. Med. 154 1249-1254 (1981).

\section{Room for Anon}

SIR - I see that you have again used the word "culprit" in connection with users of the pseudonym Isadore Nabi (Nature 29 October, p.696).

Although I refrained before, I would now like to express my conviction that the use of a pen-name, in publishing a work of literature or science, is not of itself a culpable act. Indeed, the dangers would seem to be least in theoretical science, where such contributions can normally be judged on their intrinsic qualities.

As your readers may already be familiar with literary examples, such as that of the Brontes, I will recall a few examples from mathematics.

(1) In statistics, "Student's test" is so known because it was originally published over the pen-name "Student". The author's true name is known to a few historians. Who says he did anything wrong?

(2) In Annals of Mathematics (69, 247-251; 1959) we find a letter purporting to come from a mathematician long since dead, saying how glad he is to see his results discovered independently by the mathematicians of the present day. The letter convinces me of the present day author's standing both in mathematics and in the history of mathematics; and he chose an amusing way to make his point. Who says he did anything wrong?

(3) The pen-name "N. Bourbaki" is used by a French mathematical syndicate, who have published some very useful books and gained a considerable reputation.

(4) There is some tradition that serious mathematicians, if they write an occasional piece which is recreational or humorous, may shelter behind pen-names such as "H. Petard".

Your mathematical readers can find out which journals I help to edit. I would like to assure them that I shall treat pseudonymous contributions just like any other contributions - on their merits.

J.F. AJAMS

Department of Pure Mathematics

and Mathematical Statistics,

University of Cambridge, UK 